\title{
In Vitro Evaluation of Gamma Irradiation on a Gel Formulation of Cratylia Mollis: Rheological Proporties and Microbiological Control
}

\author{
Maria Helena Madruga Lima-Ribeiro ${ }^{1}$, Ralph Santos-Oliveira ${ }^{2 *}$, Mauricélia Firmino De Santana ${ }^{3}$, \\ Terezinha De Jesus Andreoli Pinto ${ }^{4}$, Irene Satiko Kikuchi ${ }^{4}$, Cheila Gonçalves Mothé5, \\ Luana Cassandra Breitenbach Barroso Coelho ${ }^{3}$, Maria Tereza Dos Santos Correia ${ }^{3}$, \\ Ana Maria Dos Anjos Carneiro-Leão ${ }^{6}$
}

\begin{abstract}
${ }^{1}$ Laboratory of Immunopathology Keizo Asami (LIKA), Federal University of Pernambuco, Recife, Brazil; ${ }^{2}$ Nuclear Engineering Institute, Laboratory of Nanoradiopharmaceuticals, Rio de Janeiro, Brazil; ${ }^{3}$ Biochemistry Department, Federal University of Pernambuco, Recife, Brazil; ${ }^{4}$ Pharmacy Department, University of Sao Paulo, Sao Paulo, Brazil; ${ }^{5}$ School of Chemistry, Federal University of Rio de Janeiro, Rio de Janeiro, Brazil; ${ }^{6}$ Departament of Morphology and Animal Physiology, Federal Rural University of Pernambuco, Recife, Brazil.

Email: "roliveira@ien.gov.br
\end{abstract}

Received March 29 $9^{\text {th }}, 2012$; revised April 12 $2^{\text {th }}, 2012$; accepted May $12^{\text {th }}, 2012$

\begin{abstract}
Lectin Cramoll-1,4, obtained from Cratylia mollis seeds (beans camaratu) was structurally characterized, biologically and pharmacologically, but its use as a biopharmaceutical is not well documented. The objective of this study is to propose a biopharmaceutical formulation lectin Cramoll-1,4, test their hemagglutinating properties in vitro as well as the use of gamma radiation as a continuous process of decontamination formulation. It was made of the extraction and purification Cramoll-1,4, was developed a gel formulation using Carbopol ${ }^{\circledR}$ as a vehicle, at concentrations of 50, 100, 200, 300 and $600 \mu \mathrm{g}$ was irradiated with ${ }^{60} \mathrm{Co}$ gamma rays in a dose of $7.549 \mathrm{kGy} \cdot \mathrm{h}^{-1}$. The proposed formulation at a concentration of $300 \mu \mathrm{g}$ produced an increase in the hemagglutinating units Cramoll-1,4 due to the synergistic effect caused by gamma radiation. Considering the diverse use of lectins, specific molecular and structural factors, as well as changes resulting from its formulation, concentration, irradiation and route of administration is of utmost importance to continue the studies in vitro, for subsequent application in vivo to characterize the physiological and molecular processes involved in the response and cellular effects.
\end{abstract}

Keywords: Gamma Radiation; Natural Products; Hemagglutinating Activity; Cramoll-1,4

\section{Introduction}

Camaratu or Camaratuba beans (Cratylia mollis) is a forage of the semi-arid Northeast of Brazil. Natural products from plants or animals are still important sources in medical therapy. However, it takes careful pharmacological and toxicological studies to prove its efficacy and safety [1]

Lectins are proteins found in nature, often found on the cell surface or intracellular particles [2]. They have specific binding sites for carbohydrates and have the ability to interact with the molecules in biological fluids and those present on the cell surface [3]. Lectins can replace natural ligands and activate cellular responses via different intracellular signaling pathways and endocytosis of compounds formed $[4,5]$.

*Corresponding author.
Molecular forms of the lectin from seeds of $C$. mollis (Cramoll 1, Cramoll 2, Cramoll 3 and Cramoll 4) have been extensively purified and characterized [6-8]. Cramoll 1, 2 and 4 are lectins that bind specifically to glucose/ mannose, while Cramoll 3 is a galactose-specific glycoprotein. Preparations containing isoforms (Cramoll-1,4) and isolectinas (Cramoll 1, 2, 3), as well as a Cramoll were structurally analyzed and used in various biotechnological applications [8-16].

Andrade et al. [11] showed anti-tumor activity using liposomes containing the free or encapsulated Cramoll-1,4. The therapeutic use of lectins in the tissue repair process is still poorly studied. Yasuoka et al. [16] used lectins of Phaseolus vulgaris (PHA) and seed lectins from Canavalia ensiformis, Concanavalin A (ConA) in indomethacininduced intestinal ulcers in rats, there was a faster tissue repair in animals treated with lectins. 
The use of gamma rays is an alternative method for sterilization/decontamination products and raw materials. However, one of the main problems of irradiation is the occurrence of new radicals in the process. Irradiation is not a substitute for non-compliance with Good Manufacturing Practices (GMP). In fact, it should be a part of GMP [17-20].

The process of gamma radiation may not result in a radioactive product or leave any residual radioactivity. The microorganisms are killed or as a result of the destruction of a molecule or by chemical reaction of the compounds resulting from radiation. The most common treatment used is the gamma radiation levels in the control of microbial contamination of food and many other products such as pharmaceuticals and cosmetics [17].

According to the United States Pharmacopeia (USP), topical preparations should not contain microbial load exceeding the allowable limits. In many cases, the offending organisms in a cosmetic product are Escherichia coli and Pseudomonas aeruginosa. Both are especially susceptible to radiation energy at very low doses, which often means that the effect of radiation on the product is negligible [21]. Cosmetic products may be contaminated during manufacture by microorganisms in the environment or the raw materials.

Pharmacopoeia in the microbiological limits are recommended in the guidelines for a variety of cosmetic preparations. Generally, the radiation dose range of choice to achieve these levels varies between 5 and $15 \mathrm{kGy}$ [18]. However, to understand and study deeply the radiation at higher doses (100 kGy) can be used.

Gamma radiation can penetrate the packaging material and finished products containing containers closed and thus destroy the existing microorganisms. Decontamination by gamma radiation is gaining increasing attention in the production of cosmetics [20].

The ${ }^{60} \mathrm{Co}$ is commonly used for gamma irradiation, can be used for cosmetics. In order to reduce the microbiological content, this method of gamma irradiation does not leave residues that can be harmful to workers or consumers. The use of ${ }^{60} \mathrm{Co}$ also proved an effective technique in reducing pollution or contamination of the fungal flora of medicinal plants [22].

Interestingly, in different experimental conditions, characterized by different plant species, biological materials and therefore different treatment conditions also need to confirm the chemical stability of the sample, as well as the reduction or inactivation of microbial load contained therein [22-24].

The objective of this study was to develop a formulation of Cramoll-1,4 under the effect of decontamination by gamma radiation for use as a biopharmaceutical while maintaining the properties of hemagglutinating lectin.

\section{Material and Methods}

\subsection{Purification of Lectin}

An extract of seeds of C. mollis $(10 \% \mathrm{v} / \mathrm{v}$ prepared in $0.15 \mathrm{M} \mathrm{NaCl}$ ) was fractionated with ammonium sulfate $(40 \%-60 \% \mathrm{v} / \mathrm{v})$ and the fraction obtained was subjected to affinity chromatography on Sephadex G-75. Cramoll1,4 bioseletivamente was eluted with a solution of $0.3 \mathrm{M}$ D-glucose in $0.15 \mathrm{M} \mathrm{NaCl}$, dialyzed with $0.15 \mathrm{M} \mathrm{NaCl}$ for 24 hours and lyophilized according to CORREIA \& COELHO [7].

\subsection{Hemagglutinating Activity}

Hemagglutinating activity (HA) is defined as the lowest sample dilution resulting in hemagglutination [7]. Rabbit erythrocytes treated with glutaraldehyde were obtained as described by Bing et al. [25]. It was used a total dose of $15 \mathrm{kGy}$ for all irradiated samples. All preparations were tested for hemagglutination activity and protein content was determined by spectrophotometry according to Lowry et al. [26] using a calibration curve of BSA (Bovine Serum Albumin) as standard $(0-500 \mathrm{mg} / \mathrm{ml})$. For each sample to evaluate the HA was done in triplicate.

\subsection{Gel Formulation}

For all experiments, the $\mathrm{Carbopol}^{\circledR}$ was used as a vehicle (polymer powder). The polymer was suspended in a buffer solution of boric acid $(\mathrm{pH} 6.0)$ at $25^{\circ} \mathrm{C}$. This $\mathrm{pH}$ was chosen because it is similar to the $\mathrm{pH}$ of the skin. Solutions Cramoll-1,4 were added to the polymer powder and these were dissolved in buffer solution of boric acid in quantities necessary to achieve concentrations Cramoll-1,4 the end of 50,100, 200, 300 and $600 \mu \mathrm{g} / 100 \mu \mathrm{g}$ of gel. Although no preservative was used, was made the use of alcohol $96^{\circ} \mathrm{GL}$.

\subsection{Irradiation of the Gel}

Irradiation was performed at room temperature using ${ }^{60} \mathrm{Co}$ Gamma 220 cells available at the Federal University of Rio de Janeiro, at a dose rate of $7549 \mathrm{kGy} \cdot \mathrm{h}^{-1}$. Samples (Cramoll-1,4 and gel formulation Cramoll-1,4) in glass vials were irradiated with doses of 10 and $100 \mathrm{kGy}$. Irradiated samples were used as controls to detect changes physico-chemical, biological and microbiological resulting from the action of ionizing radiation on the products.

\subsection{Rheological Analysis}

The rheological measurements were performed on a Brookfield viscometer, model LVIII, CP52 cone-plate 
sensor shaft with shear rate from 0 to $200(\mathrm{~Hz})$ and temperature controlled at $25^{\circ} \mathrm{C}$ with thermostat TC501.

\subsection{Antimicrobial Activity in Vitro}

\subsubsection{Strains}

The following strains of microorganisms were used to develop this work: Aspergillus niger ATCC 16404, Candida albicans ATCC 10231, Escherichia coli ATCC 8739, Pseudomonas aeruginosa ATCC 9027, Staphylococcus aureus ATCC 6538, Bacillus subtilis ATCC 6633. Bacteria were grown in Tryptic Soy Agar and yeast in Sabouraud Dextrose Agar.

\subsubsection{Validation of Method}

Harmless microorganism of each test was prepared by serial dilution of the suspension of stock. Then $100 \mathrm{~mL}$ of each test organism (Table 1) were transferred to Petri dishes containing $100 \mathrm{~mL}$ of gel excipient. The culture media $(15 \mathrm{~mL})$ were added to each plate. Fungi were incubated at $22.5^{\circ} \mathrm{C} \pm 2.5^{\circ} \mathrm{C}$ and bacteria in $32.5^{\circ} \mathrm{C} \pm$ $2.5^{\circ} \mathrm{C}$. A. niger was incubated for $6-10$ days and yeasts during $18-24 \mathrm{~h}$. All tests were performed in triplicate, and just over $70 \%$ of recovery levels were considered.

\subsubsection{Treatment of Samples}

Quantities of $1.0 \mathrm{~g}$ of sample were added into sterilized jars that have been intentionally contaminated with 100 $\mathrm{mL}$ of each strain of microorganism (Table 2) and subjected to separate doses of 10 and $100 \mathrm{kGy}$ of gamma radiation from a ${ }^{60} \mathrm{Co}$ source. After this treatment, $1 \mathrm{~mL}$ of each sample was transferred to a petri dish and prepared for microbial count (Table 1).

\section{Results}

The microbiological analysis (Table 1) showed that all microorganisms were recovered efficiently, providing vali- dation of the method used to evaluate the effect of gamma rays in the samples. The Table 2 shows that doses of 10 and $100 \mathrm{kGy}$ gamma were effective for the treatment of previously contaminated samples.

The results of rheological analysis were important, especially after irradiation of the gel. The analysis of Figure 1 shows the apparent viscosity versus the shear rate for samples non-irradiated and irradiated with 10 and $100 \mathrm{kGy}$ and can be observed that for all samples, the apparent viscosity decreased with increasing dose of irradiation at a constant shear rate, so for an irradiation

Table 1. Recovery of inoculated microorganisms in samples of gel.

\begin{tabular}{lcc}
\hline Microorganism & $\begin{array}{c}\text { Amount of Microorganisms } \\
\text { Inoculated (100 } \boldsymbol{\mu L} \text { ) }\end{array}$ & $\begin{array}{c}\text { Recovery of } \\
\text { Microorganisms }\end{array}$ \\
\hline A. niger & 29 UFC & $84.3 \%$ \\
C. albicans & 8 UFC & $100.0 \%$ \\
E. coli & 49 UFC & $89.8 \%$ \\
P. aeruginosa & 76 UFC & $100.0 \%$ \\
S. aureus & 44 UFC & $100.0 \%$ \\
B. subtilis & 49 UFC & $91.5 \%$ \\
\hline
\end{tabular}

Table 2. Effect of gamma rays in the contaminated samples.

\begin{tabular}{|c|c|c|c|}
\hline \multirow[b]{2}{*}{ Microorganism } & \multicolumn{3}{|c|}{ Dose of Gamma Rays } \\
\hline & $\begin{array}{l}\text { No Treatment (Initial } \\
\text { Amount of Harmless) }\end{array}$ & 10 kGy & 100 kGy \\
\hline A. niger & $8.4 \times 10^{3} \mathrm{UFC} / \mathrm{g}$ & $<10 \mathrm{UFC} / \mathrm{g}$ & $<10 \mathrm{UFC} / \mathrm{g}$ \\
\hline C. albicans & $7.1 \times 10^{3} \mathrm{UFC} / \mathrm{g}$ & $<10 \mathrm{UFC} / \mathrm{g}$ & $<10 \mathrm{UFC} / \mathrm{g}$ \\
\hline E. coli & $5.8 \times 10^{4} \mathrm{UFC} / \mathrm{g}$ & $<10 \mathrm{UFC} / \mathrm{g}$ & $<10 \mathrm{UFC} / \mathrm{g}$ \\
\hline P. aeruginosa & $7.6 \times 10^{4} \mathrm{UFC} / \mathrm{g}$ & $<10 \mathrm{UFC} / \mathrm{g}$ & $<10 \mathrm{UFC} / \mathrm{g}$ \\
\hline S. aureus & $5.4 \times 10^{4} \mathrm{UFC} / \mathrm{g}$ & $<10 \mathrm{UFC} / \mathrm{g}$ & $<10 \mathrm{UFC} / \mathrm{g}$ \\
\hline B. subtilis & $10^{6} \mathrm{UFC} / \mathrm{g}$ & $<10 \mathrm{UFC} / \mathrm{g}$ & $<10 \mathrm{UFC} / \mathrm{g}$ \\
\hline
\end{tabular}

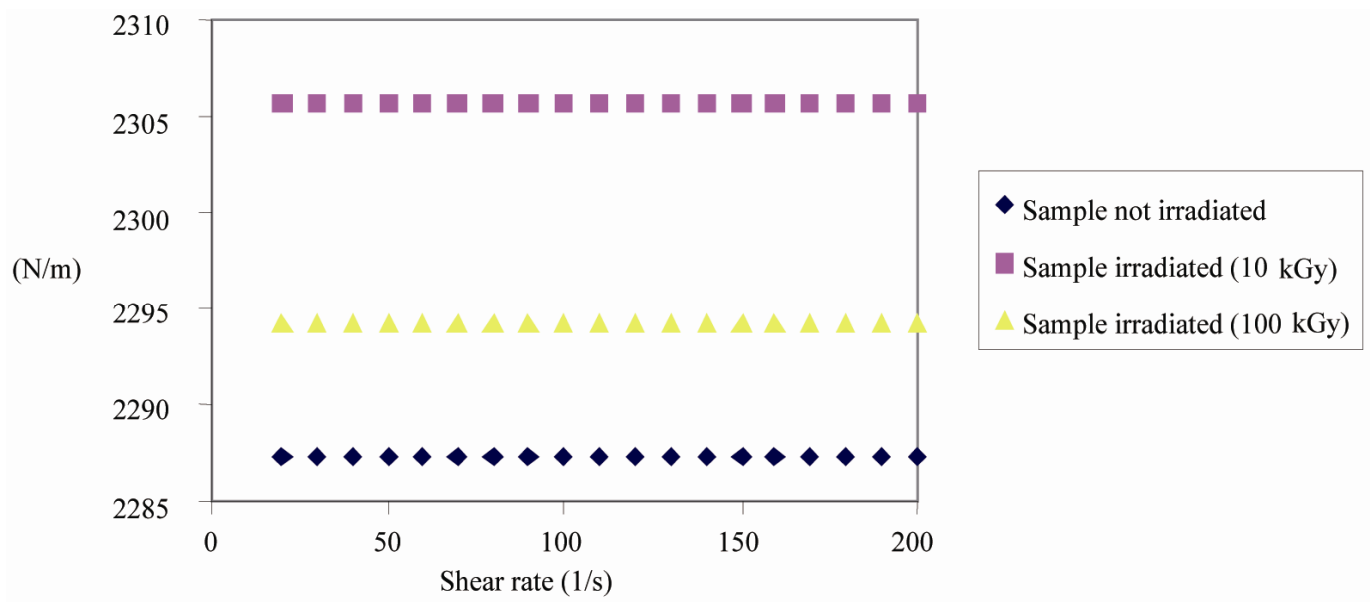

Figure 1. Analysis of the gel by different rheological conditions. 
dose of $100 \mathrm{kGy}$ was $20 \mathrm{mPa} . \mathrm{s}$ viscosity $(2.295 \mathrm{~N} / \mathrm{m})$ for all samples.

The gel excipient, as desired, showed not hemagglutinating activity (Figure 2). However, it was observed that the Cramoll-1,4, at a concentration of $50 \mu \mathrm{g}$, both Cramol-1,4 native and the formulation under the influence of radiation lost their hemagglutinating activity. However as we increased the concentration of lectin $(100 \mu \mathrm{g})$, these changes were not observed. At a concentration of $200 \mu \mathrm{g}$, there was a reduction in the hemagglutinating activity Cramoll-1,4 native and radiated in the formulation, however, allowed the maintenance of a good title for hemagglutinating activity.

According to Figure 2 the hemagglutinating activity of Cramoll-1,4 gels at a concentration of $300 \mu \mathrm{g}$ was maintained after irradiation while Cramoll-1,4 native lost this activity. The formulation irradiated at a concentration of $600 \mu \mathrm{g}$ of Cramoll-1,4 reached an undesirable level of HA different from zero, as occurred with the native form irradiated. This suggests that the gel has a "protective" effect on the Cramoll-1,4, especially against hydrolysis by maintaining the activity of the lectin longer.

These data suggest that gamma irradiation at a dose of $15 \mathrm{kGy}$ at a concentration of $300 \mu \mathrm{g}$ can be used as an alternative process for the microbial control of drugs based on Cramoll-1,4 and maintenance of a satisfactory title hemagglutinating activity.

\section{Discussion}

The results microbiological analysis (Table 1) corroborate the literature on the use of irradiation for decontamination.
The results in Table 1 suggest the routine use of gamma radiation for the decontamination of biopharmaceuticals and cosmetics, which is consistent with the observations of MAHER \& DIETZ [27] who claim that irradiation plays an increasingly important role in the decontamination of cosmetic and medicinal products.

The results of rheological analysis (Figure 1) indicates that the dose of $100 \mathrm{kGy}$ is not recommended since it reduces the viscosity of the gel. This viscosity represents one of the most important factors in using this formulation because it allows a greater adherence material tissue under study. Several aspects make the gel formulation an ideal introduction for the treatment of tissue lesions, such as biocompatibility, no toxicity, biodegradability, adhesion and absorption [28,29].

According to the results obtained from the evaluation of hemagglutinating activity, it is possible to develop an in vivo study, so it will be possible to evaluate the effect of this formulation in the tissue repair process, since several experimental studies have reported the effect of using lectins mannose-glucose in the repair skin lesions [30,31], be effective as therapeutic agents and reducing the time of tissue repair. We evaluated the effects on the repair of cutaneous lesions in normal mice using the isoforms 1 and 4 of Cratylia mollis lectin [32] and in immunosuppressed animals by the use of methotrexate, a study by Melo et al. [33], which had their injuries repaired efficiently and in less time.

\section{Conclusion}

The gel formulation of the radiated Cramoll-1,4 at a

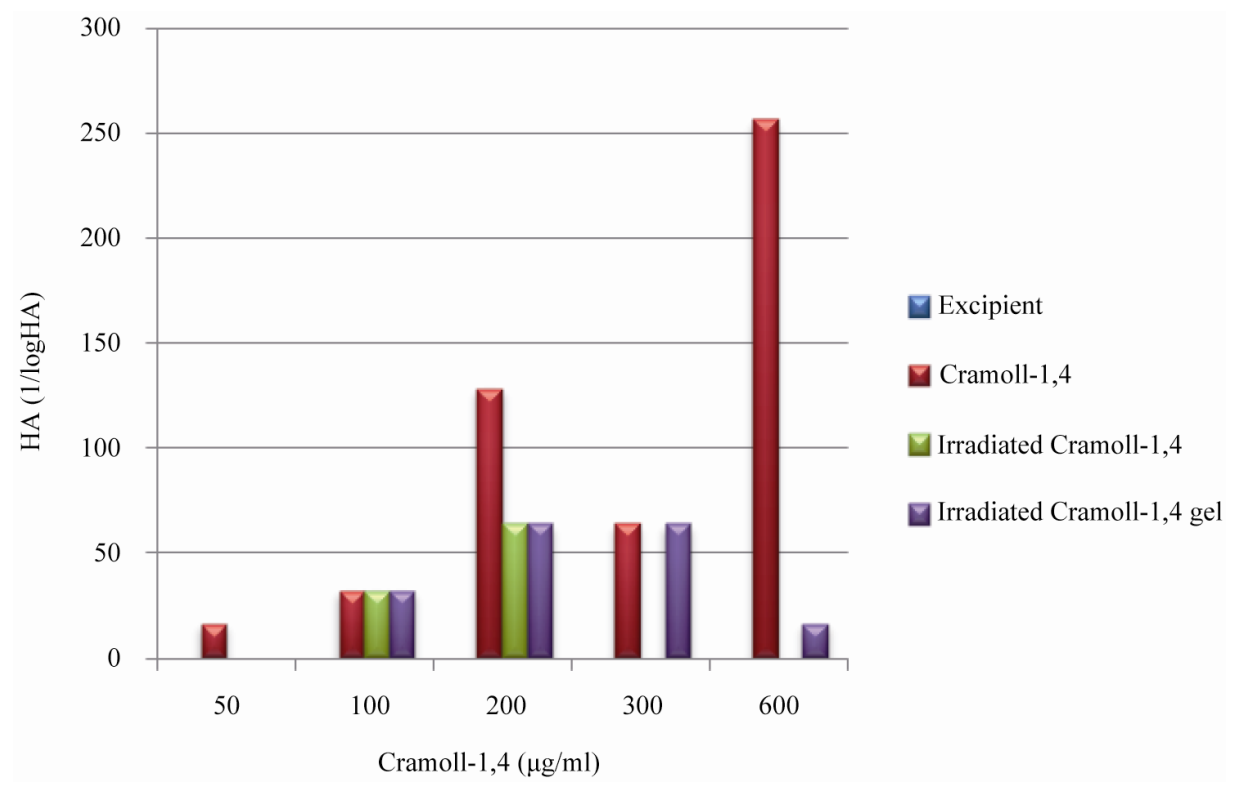

Figure 2. Evaluation of hemagglutinating activity of Cramoll-1,4 native and under the effect of radiation at a dose of $15 \mathrm{kGy}$. The data refer to comparisons of samples irradiated or not within the same concentration. 
concentration of $300 \mu \mathrm{g}$ was adequate for the maintenance of hemagglutinating activity, suggesting its topical application in vivo. The gamma irradiation was effective in controlling microbial formulation. It is suggested to continue their studies, particularly regarding the effects of this formulation in vivo.

\section{Acknowledgements}

The Department of Energy's Nuclear UFPE/FINEP and the Nuclear Energy Institute in Rio de Janeiro.

\section{REFERENCES}

[1] P. J. Houghton, et al., "In Vitro Tests and Ethnopharmacological Investigations: Wound Healing as an Example," Journal of Ethnopharmacology, Vol. 100, No. 1-2, 2005, pp. 100-107. doi:10.1016/j.jep.2005.07.001

[2] N. Sharon and H. Lis, "A Century of Lectin Research (1888-1988)," Trends Biochemical Science, Vol. 12, 1987, pp. 483-487.

[3] M. T. S. Correia, L. C. B. B. Coelho and P. M. G. Paiva, "Lectins Carbohydrate Recognition Molecules: Are They Toxic?" In: Y. H. Siddique, Ed., Full name Recent Trends in Toxicology, Transworld Research Network, Kerala, 2008, pp. 47-59.

[4] J. Beuth, H. L. Ko, G. Pulverer, G. Uhlenbruck and H. Pichlmaier, "Importance of Lectins for the Prevention of Bacterial Infections and Cancer Metastases," Glycoconjugate Journal, Vol. 12, No. 1, 1995, pp. 1-6. doi:10.1007/BF00731862

[5] M. Hong, A. Cassely, Y. Mechref and M. V. Novotny, "Sugar-Lectin Interactions Investigated through Affinity Capillary Electrophoresis," Journal of Chromatography B: Biomedical Sciences and Applications, Vol. 752, No. 2, 2001, pp. 207-216. doi:10.1016/S0378-4347(00)00564-8

[6] P. M. G. Paiva and L. C. B. B. Coelho, "Purification and Partial Characterization of Two Lectin Isoforms from Cratylia mollis Mart (Camaratu Bean)," Applied Biochemistry and Biotechnology, Vol. 36, No. 2, 1992, pp. 113-119. doi:10.1007/BF02929691

[7] M. T. S. Correia and L. C. B. B. Coelho, "Purification of a Glucose/Manose Specific Lectin, Isoforma 1, from Seeds of Cratylia mollis Mart (Camaratu Bean)," Applied Biochemistry and Biotechnology, Vol. 55, No. 3, 1995, pp. 261-273. doi:10.1007/BF02786865

[8] G. A. De Souza, P. S. Oliveira, S. Trapani, A. C. Santos, J. C. Rosa, H. J. Laure, et al., "Amino Acid Sequence and Tertiary Structure of Cratylia mollis Seed Lectin," Glycobiology, Vol. 13, No. 12, 2003, pp. 961-972. doi:10.1093/glycob/cwg115

[9] V. L. M Lima, M. T. S. Correia, Y. M. N. Cechinel, C. A. M. Sampaio, J. S. Owen and L. C. B. B. Coelho, "Immobilized Cratylia mollis Lectin as a Potential Matrix to Isolate Plasma Glycoproteins, including Lecithin-Cholesterol Acyltransferase," Carbohydrate Polymers, 1997, Vol. 33, No. 6, pp. 27-32.
[10] E. I. Beltrão, M. T. Correia, J. Figueredo-Silva and L. C. Coelho, "Binding Evaluation of Isoform 1 from Cratylia mollis Lectin to Human Mammary Tissues," Applied Biochemistry and Biotechnology, Vol. 74, No. 3, 1998, pp. 125-134. doi:10.1007/BF02825961

[11] P. M. Paiva, A. F. Souza, M. L. Oliva, J. F. Kennedy, M. S. Cavalcanti, L. C. Coelho, et al., "Isolation of a Trypsin Inhibitor from Echinodorus paniculatus Seeds by Affinity Chromatography on Immobilized Cratylia mollis Isolectins," Bioresource Technology, Vol. 88, No. 1, 2003, pp. 75-79. doi:10.1016/S0960-8524(02)00272-9

[12] E. V. Maciel, V. S. Araújo-Filho, M. Nakazawa, Y. M. Gomes, L. C. Coelho and M. T. Correia, "Mitogenic Activity of Cratylia mollis Lectin on Human Lymphocytes," Biologicals, Vol. 32, No. 1, 2004, pp. 57-60. doi:10.1016/j.biologicals.2003.12.001

[13] C. A. S. Andrade, M. T. S. Correia, L. C. B. B. Coelho, S. C. Nascimento and N. S. Santos-Magalhães, "Antitumor Activity of Cratylia mollis Lectin Encapsulated into Liposomes," Vol. 278, No. 2, 2004, pp. 435-445. doi:10.1016/j.ijpharm.2004.03.028

[14] M. D. L. Oliveira, "Estudo Bioeletroquímico de Nanosistemas Híbridos de Nanopartículas de Ouro E Lectinas Para O Desenvolvimento de Sensores," Ph.D. Thesis, Federal University of Pernambuco, Recife, 2008.

[15] R. Angeli, N. V. N. da Paz, J. C. Maciel, F. F. B. Araújo, P. M. G. Paiva, G. M. T. Calazans, et al., "Ferromagnetic Levan Composite: An Affinity Matrix to Purify Lectin," Journal of Biomedicine and Biotechnology, Vol. 2009, 2009, Ariticle ID: 179106. doi:10.1155/2009/179106

[16] T. Yasuoka, M. Sasaki, T. Fukunaga, T. Tsujikawa, Y. Fujiyama, R. Kushima, et al., "The Effects of Lectins on Indomethacin-Induced Small Intestinal Ulceration," International Journal of Experimental Pathology, Vol. 84, No. 5, 2003, pp. 231-237. doi:10.1111/j.1365-2613.2003.00360.x

[17] B. D. Reid and B. K. Wilson, "Radiation Processing Technology for Cosmetics," Radiation Physics and Chemistry, Vol. 42, No. 4-6, 1993, pp. 595-596. doi:10.1016/0969-806X(93)90331-N

[18] G. P. Jacobs, "A Review of the Effect of Gamma Irradiation on Pharmaceutical Materials," Journal of Biomaterials Applications, Vol. 10, 1995, pp. 61-72.

[19] N. Barbarin, B. Tilquin and E. Dehoffmann, "Radiosterilization of Cefotaxime: Investigation of Potential Degradation Compounds by Liquid Chromatography Electrospray Mass Spectrometry," Journal of Chromatography A, Vol. 929, No. 1-2, 2001, pp. 51-61. doi:10.1016/S0021-9673(01)01175-X

[20] N. Naki Sivri, A. Y. Özer, M. Özalp, N. Atakan and M. Polat, "Decontamination of Cosmetics Products and Raw Materials by Gamma Irradiation," Journal of Pharmaceutical Sciences, Vol. 31, 2006, pp. 198-209.

[21] G. R. Dietz and W. J. Maher, "Radiation Sterilization in the Cosmetic Industry Update," Cosmetics \& Toiletries, Vol. 97, 1982, pp. 96-98.

[22] G. Prado, M. C. Andrade, M. S. Oliveira, A. S. Leal, B. R. Oliveira and L. R. Batista, "Efeito da Irradiação na Micro- 
biota Fúngica de Plantas Medicinais," Ciência Agrotecnologia, Vol. 33, No. 5, 2009, pp. 1372-1378.

[23] L. C. Satomi, R. R. Soriani and T. J. A. Pinto, "Descontaminação de Drogas Vegetais Empregando Irradiação Gama e Óxido de Etileno: Aspectos Microbianos e Químicos," Revista Brasileira de Ciencias Farmaceuticas, Vol. 41, No. 4, 2005, pp. 445-450.

[24] R. S. Oliveira and W. Colaço, "Radiossensitividade Gama de Extrato de Maytenus ilicifolia: Desenvolvimento de Protocolo Para Controle de Qualidade," Latin American Journal of Pharmacy, Vol. 27, No. 2, 2008, pp. 235-239.

[25] D. H. Bing, J. G. M. Weyand and A. B. Stavinsky, "Hemagglutination with Aldeyde-Fixed Erythrocytes for Assay of Antigens and Antibodies," Proceedings of the Society for Experimental Biology and Medicine, Vol. 124, No. 4, 1967, pp. 1166-1170.

[26] O. H. Lowry, N. J. Rosebrough, A. L. Farr and R. J. Randall, "Protein Measurement with the Folin Phenol Reagent," The Journal of Biological Chemistry, Vol. 193, No. 1,1951 , pp. 265-275.

[27] W. J. Maher and G. R. Dietz, "Radiation Sterilization in the Cosmetic Industry," Cosmetics \& Toiletries, Vol. 96, 1981, pp. 53-58.

[28] N. Roy, et al., "Permeability and Biocompatibility of Novel Medicated Hydrogel Wound Dressings," Soft Materials, Vol. 8, No. 4, 2010, pp. 338-357. doi:10.1080/1539445X.2010.502955
[29] N. Roy, N. Saha, T. Kitano and P. Saha, "Novel Hydrogels of PVP-CMC and Their Swelling Effect on Viscoelastic Properties," Journal of Applied Polymer Science, Vol. 117, No. 3, 2010, pp. 1703-1710.

[30] S. Choi and M. Chung, "A Review on the Relationship between Aloe Vera Components and Their Biologic Effects," Seminars in Integrative Medicine, Vol. 1, No. 1, 2003, pp. 53-62. doi:10.1016/S1543-1150(03)00005-X

[31] G. C. Lopes, A. C. Sanches, C. V. Nakamura, B. P. Dias Filho, L. Hernandes and J. C. de Mello, "Influence of Extracts of Stryphnodendron polyphyllum Mart. and Stryphnodendron obovatum Benth. on the Cicatrisation of Cutaneous Wounds in Rats," Journal of Ethnopharmacology, Vol. 99, No. 2, 2005, pp. 265-272. doi:10.1016/j.jep.2005.02.019

[32] C. M. L. Melo, E. R. C. Albuquerque, M. M. M. Oliveira, L. C. B. B. Coelho, M. C. O. C Coelho, M. T. S. Correia, et al., "Topical Use of Cratylia mollis Lectin in Wound Healing in Mice," Reunião Anual da Sociedade Brasileira de Bioquímica e Biologia Molecular, SBBq, Recife, 2003, p. 112.

[33] C. M. L. Melo, C. S. Porto, M. R. Melo-Júnior, C. M. Mendes, C. C. B. Cavalcanti, L. C. B. B. Coelho, et al., "Healing Activity Induced by Cramoll 1,4 Lectin in Healthy and Immunocompromised Mice," International Journal of Pharmaceutics, Vol. 408, No. 1-2, 2011, pp. 113-119. doi:10.1016/j.ijpharm.2011.02.011 